\author{
Agata Dziekan-Łanucha \\ Uniwersytet Papieski Jana Pawła II w Krakowie
}

\title{
ODPOWIEDZIALNOŚĆ NADAWCÓW RADIOWYCH I TELEWIZYJNYCH ZA EMITOWANE TREŚCI NA GRUNCIE USTAWY MEDIALNEJ ORAZ JEJ EGZEKWOWANIE Przez KRajową Radę RadiofoniI i TelewizJI
}

\begin{abstract}
Responsibility of broadcasters for contents of radio and television programs in the light of the Broadcasting Act and enforcing this responsibility by the National Broadcasting Council. Article 18 of the Broadcasting Act contains among other things regulations pointing that broadcasters cannot show programs, which encourage actions contrary to law, propagate attitudes and beliefs contrary to the moral values and social interest, include broadcasts discriminating on grounds of race, sex and nationality, do not respect the religious beliefs of the public, especially the Christian system of values. Regulations also forbid to broadcast programs which may threaten the physical, mental or moral development of minors. The paper presents examples of broadcasts whose contents break the regulations of the article 18. These are going to be the cases which were brought under control of the National Broadcasting Council, because in accordance with the Broadcasting Act this regulatory is entitled to enforce this Act and call broadcasters to account. The paper also shows the Council's activity concerning creating precise regulations as to the protection of the youngest audience from harmful broadcasts. This article includes the assessment of the activities of the Council itself in the field of program supervision of broadcasters.
\end{abstract}

Artykuł 18 ustawy o radiofonii i telewizji zawiera m.in. zapisy mówiące o tym, że nadawcy radiowi i telewizyjni nie mogą emitować audycji, które propagują działania sprzeczne z prawem, poglądy sprzeczne z moralnością i dobrem społecznym; które zawierają treści dyskryminujące ze względu na rasę, płeć lub narodowość, które nie szanowałyby uczuć religijnych odbiorców, a zwłaszcza godziłyby w chrześcijański system wartości. Unormowania wskazują także na zakaz emisji audycji mogących zagrażać fizycznemu, psychicznemu lub moralnemu rozwojowi małoletnich. W referacie zostały przedstawione przykłady nadawania audycji, których treści sprzeciwiają się regulacjom artykułu 18. Są to przypadki, które zostały poddane kontroli Krajowej Rady Radiofonii i Telewizji, ponieważ to organ regulacyjny w świetle ustawy o radiofonii i telewizji jest uprawniony do egzekwowania ustawowych unormowań i pociągania nadawców do odpowiedzialności. Pokazana też została aktywność Rady 
dotycząca tworzenia szczegółowych przepisów w zakresie ochrony najmłodszych odbiorców przed szkodliwymi treściami. W artykule znajduje się także ocena poczynań samej Krajowej Rady właśnie w obszarze nadzoru programowego nad nadawcami.

Keywords: broadcasters, responsibility, the National Broadcasting Council, social interest, protection of minors

nadawcy, odpowiedzialność, Krajowa Rada Radiofonii i Telewizji, dobro społeczne, ochrona małoletnich

Do dbałości o rodzaj emitowanych treści skłania nadawców artykuł 18 ustawy o radiofonii i telewizji. W swoich ustępach 1, 2 i 3 zakazuje on nadawać audycje, które propagują działania sprzeczne z prawem, polską racją stanu oraz poglądy i postawy zagrażające zdrowiu lub bezpieczeństwu oraz zachowania zagrażające środowisku naturalnemu; które zawierają treści dyskryminujące ze względu na rasę, płeć lub narodowość; które nie szanowałyby uczuć religijnych odbiorców, a zwłaszcza godziłyby w chrześcijański system wartości. W kolejnych wskazuje na szczególną troskę wobec młodszych widzów i słuchaczy, zakazując w ogóle nadawania audycji zagrażających prawidłowemu rozwojowi małoletnich i pozwalając nadawać audycje, które mogłyby wpłynąć negatywnie na ich rozwój, tylko poza czasem chronionym ${ }^{1}$.

Szczególna odpowiedzialność za rodzaj emitowanych treści, jaką obarcza się nadawców, to przede wszystkim efekt ich wyjątkowej intensywności i zakresu oddziaływania. Z racji swych ogromnych możliwości docierania i wpływania na szerokie grupy odbiorców media elektroniczne musiały zostać poddane ścisłemu nadzorowi. Nastąpiło ograniczenie ich wolności i niezależności. To ograniczenie nie może jednak przekraczać niezbędnego minimum i musi być skutkiem harmonizowania wolności słowa nadawców z prawem odbiorców do informacji oraz z wymaganiami interesu społecznego, o czym już w 1994 roku mówił w swojej uchwale Trybunał Konstytucyjny². Organem powołanym do przeprowadzania nadzoru programowego nad nadawcami jest Krajowa Rada Radiofonii i Telewizji. Czynności, które podejmuje w tym zakresie, nie mają charakteru przypadkowego. W toku swoich działań Rada wypracowała system kontroli programowej nadawców. Sprawdzanie programów radiowych i telewizyjnych odbywa się na podstawie sprawozdań składanych co roku przez nadawców publicznych i komercyjnych oraz na podstawie monitoringu audycji, który przeprowadzany jest tylko na materiale poemisyjnym ${ }^{3}$. Fakt, iż monitoring dotyczy tylko materiału poemisyjnego, jest bardzo istotny. Nadzór ze strony Rady nie może bowiem przybrać formy kontroli w postaci cenzury uprzedniej

Powyższe działania Rada może wykonywać bez przeszkód, ponieważ ustawa o radiofonii i telewizji zagwarantowała jej przewodniczącemu odpowiednie środki kontroli.

\footnotetext{
1 Por. Ustawa o radiofonii i telewizji, Dz.U. z 1993 roku, nr 7, poz. 34, z późn. zm.

2 Uchwała Trybunału Konstytucyjnego z dnia 2 marca 1994 roku, sygn. akt W 3/93, Przegląd Sejmowy, 1994, nr 2, s. 328-334.

3 Krajowa Rada Radiofonii i Telewizji, Sprawozdanie Krajowej Rady Radiofonii i Telewizji z rocznego okresu działalności, Warszawa, marzec 2000, s. 67, http://www.krrit.gov.pl/Data/Files/_public/Portals/0/sprawozdania/spr2000/spr2000.pdf (09.08.2011).

4 P. Czarny, Podstawowe prawa i wolności obywatelskie, [w:] Prawo konstytucyjne, red. P. Tuleja, Warszawa 1997, s. 83.
} 
Przewodniczący bowiem może żądać od nadawcy przedstawienia wszelkich materiałów i dokumentów niezbędnych do sprawdzenia działalności programowej5.

Ustawa umożliwia Radzie także przywoływanie do porządku (poprzez zastosowanie sankcji) nadawców, którzy łamią przepisy dotyczące działalności programowej. Sankcja przewidziana jest już w sytuacji, gdy owego żądania przewodniczącego dotyczącego udostępnienia potrzebnych materiałów i dokumentów osoba kierująca działalnością nadawcy nie wypełni. Przewodniczący może wtedy podjąć decyzję o nałożeniu na nią kary finansowej w wysokości nieprzekraczającej równowartości jej sześciomiesięcznego wynagrodzenia.

Kiedy Rada stwierdzi, że działalność programowa nadawcy jest nieprawidłowa, jej przewodniczący może wezwać nadawcę do zaniechania tych naruszających normy czynności, a gdy to nie odniesie skutku, na podstawie uchwały Rady może wydać decyzję nakazującą ich zaniechania albo też decyzję już bardziej restrykcyjną o nałożeniu kary pieniężnej na nadawcę w kwocie do 50 proc. rocznej opłaty za używanie częstotliwości, a gdy nadawca nie uiszcza tej opłaty - w wysokości do 10 proc. jego przychodów $\mathrm{z}$ poprzedniego roku podatkowego ${ }^{6}$.

Z decyzją nakazującą zaniechania określonego sposobu postępowania związane są konsekwencje dla osoby reprezentującej nadawcę. Jeśli nie dostosuje się do tej decyzji, grozi jej ze strony przewodniczącego nałożenie kary pieniężnej w kwocie takiej samej jak w przypadku nieudostępnienia żądanych dokumentów?

Kara dla nadawcy w wysokości do 50 proc. opłaty za częstotliwość lub do 10 proc. przychodów jest także możliwa do nałożenia przez przewodniczącego KRRiT, kiedy nadawca łamie któryś z wyszczególnionych w ustawie artykułów lub rozporządzeń Rady wydanych na ich podstawie. Przewodniczący może zastosować taką sankcję, kiedy nadawca nie przestrzega w programie kwot audycji ${ }^{8}$, nie stosuje się do przepisów o emisji reklam oraz o sponsorowaniu, gdy nie przestrzega aktów prawnych wydanych w tych dziedzinach przez Radę oraz aktu określającego zasady nadawania programów mogących zagrażać prawidłowemu rozwojowi dzieci i młodzieży9 .

Łamanie norm działalności programowej może też skutkować bardziej surową sankcją niż obciążenia finansowe. Krajowa Rada na podstawie artykułu 38 punkt 4 ustawy o RTV ma prawo w takiej sytuacji nawet odebrać nadawcy koncesję ${ }^{10}$.

\section{EgZEKWOWANIE ZAPISÓW ZABRANIAJĄCYCH PROPAGOWAĆ DZIALANIA SPRZECZNE Z PRAWEM,} NARUSZAJĄCE UCZUCIA RELIGIJNE, SPRZECZNE Z MORALNOŚCIĄ I DOBREM SPOLECZNYM

Od strony formalnej sposób postępowania Rady wobec nadawców jest więc jasno określony. Kłopotów może nastręczać natomiast samo stwierdzenie, czy nadawca złamał normy podane w artykule 18, w tym szczególnie w ustępach 1, 2 i 3. Jego zapisy

J. Sobczak, Radiofonia i telewizja. Komentarz do ustawy, Zakamycze 2001, s. 135.

Wynika to z art. 10 ust. 4 oraz art. 53 ust. 2 ustawy o radiofonii i telewizji.

Wynika to z art. 54 ust. 1 ustawy o radiofonii i telewizji.

8 Niektóre rodzaje audycji muszą mieć w programie nadawcy ściśle określony udział procentowy.

Wynika to z art. 53 ust. 1 ustawy o radiofonii i telewizji.

10 Art. 38 pkt 4 mówi, że koncesja może być cofnięta, jeżeli działalność objęta koncesją jest wykonywana w sposób sprzeczny z ustawą lub warunkami określonymi w koncesji. 
bowiem mają charakter pojęć niedookreślonych lub odsyłających do wartości pozaprawnych funkcjonujących $w$ społeczeństwie ${ }^{11}$. $Z$ tego względu pojęcia te można interpretować $\mathrm{w}$ różny sposób, nadając im za każdym razem odmienne znaczenie ${ }^{12}$. Zapisy o tym kształcie, dopuszczające tak daleko idącą dowolność interpretacyjną nie są więc dobrze postrzegane przez znawców prawa. Pojawiają się nawet opinie, że „w odniesieniu do omawianych przepisów zarówno ilość, jak i sformułowanie poszczególnych klauzul wykraczają poza racjonalne granice"13.

Niektórzy prawnicy to na Krajową Radę przenoszą obowiązek interpretacji zapisów ustawowych i oceniania audycji na podstawie własnych analiz. Wydaje się jednak, że jest to przedsięwzięcie o dużym stopniu trudności i jego realizacja w praktyce może wywołać liczne kontrowersje. Rada samodzielnie interpretując paragrafy artykułu 18 , łatwo może narazić się na protesty ze strony nadawców, że owe sformułowania źle rozumie, interpretuje za szeroko albo wykorzystuje je do tego, żeby ograniczać wolność wypowiedzi.

Należy więc wnioskować, że właśnie z tego względu Krajowa Rada w toku swojej działalności przeprowadzając czynności nadzorcze, stosunkowo rzadko powoływała się na zapisy zawarte w ustępie 1, 2 i 3 omawianego artykułu, nie stwierdzając, aby któryś z kontrolowanych nadawców je łamał.

Jednoznacznie brzmiące stanowisko, że oto nadawca dopuszcza się postępowania sprzecznego z artykułem 18 wydała Rada w stosunku do Radia City ze Słupska. Krajowa Rada postanowiła przyjrzeć się bliżej tej stacji, zaniepokojona publikacjami prasowymi na temat jej kontrowersyjnej działalności. Szczególnie wnikliwej analizie poddała dwie audycje radiowe Talk show i Piwne rozmowy. Po przyjrzeniu się bliżej treściom zawartym w tych pozycjach programowych Rada wyraziła opinię, że nadawca przekracza w nich zakazy określone w artykule 18, a w szczególności dopuszcza się propagowania postaw i poglądów sprzecznych z moralnością i dobrem społecznym oraz obraża uczucia religijne odbiorców.

Stacja radiowa zgodnie z obowiązującą procedurą otrzymała najpierw od przewodniczącego Rady wezwanie do zaniechania emisji powyższych audycji. Kilka miesięcy później Rada rozpoczęła rekontrolę rozgłośni, chcąc sprawdzić efekty napomnienia. Wyniki monitoringu dalekie od zadowalających oraz płynące do Rady skargi na nadawcę skłoniły ten organ do podjęcia restrykcyjnej decyzji o wszczęciu procedury cofnięcia koncesji nadawcy.

Łamaniem norm dobrego obyczaju oraz obrazą uczuć religijnych zajmowała się Rada także w odniesieniu do telewizji komercyjnej. Oskarżenia o tego rodzaju naruszenia związane były z wypowiedziami Janusza Rewińskiego w programie Ale pla$m a$ wyemitowanym 22 stycznia 1999 roku w TVN. Informację o tym Rada uzyskała od widzów, którzy przysłali do jej biura pisemne skargi. Wezwanie przewodniczącego KRRiT do przeciwdziałania pojawianiu się w programie szkodliwych treści przyniosła pozytywny efekt. Kilka tygodni później prezes TVN Mariusz Walter wystąpił na ekranie

\footnotetext{
11 Prawo radiofonii i telewizji w świetle standardów europejskich, red. C. Banasiński, Warszawa, 2001, s. 60 .

12 A. Matlak, Radiofonia i telewizji, [w:] Prawo mediów, red. J. Barta, R. Markiewicz, A. Matlak, Warszawa 2005, s. 168.

13 Tamże, s. 168.
} 
z przeprosinami dla wszystkich widzów, którzy poczuli się urażeni wypowiedziami prowadzącego program ${ }^{14}$.

Również pod wpływem zgłaszanych skarg Krajowa Rada postanowiła bliżej przyjrzeć się programowi typu reality show pod tytułem Amazonki emitowanemu w 2001 roku przez stację TV 4. Potwierdziła trafność spostrzeżeń skarżących. Uznała, że w programie tym propaguje się zachowania sprzeczne z prawem oraz poglądy sprzeczne z moralnością i dobrem społecznym, znajdując tym samym podstawy do interwencji. Krajowa Rada przyjęła więc uchwałę zobowiązującą przewodniczącego tego gremium do wydania decyzji wzywającej nadawcę do zaniechania działań wywołujących te naruszenia ${ }^{15}$.

Najgłośniejsze przypadki interwencji Rady wobec nadawców ze względu na złamanie analizowanych norm wiążą się z programem Kuba Wojewódzki. W 2006 roku przewodniczący KRRiT nałożył na Polsat 500 tys. zł kary za emisję odcinka z udziałem Kazimiery Szczuki. W audycji tej Kazimiera Szczuka parodiowała głos spikerki Radia Maryja Magdaleny Buczek, czemu towarzyszyły pogardliwe komentarze prowadzącego. Zdaniem szefa Krajowej Rady doszło do naruszenia uczuć religijnych osób wierzących, a także do naruszenia dóbr osobistych Magdaleny Buczek. Sądy w kolejnych instancjach, do których odwoływał się Polsat, podtrzymywały słuszność decyzji przewodniczącego Krajowej Rady ${ }^{16}$. Spór został ostatecznie zakończony oddaleniem skargi kasacyjnej przez Sąd Najwyższy 14 stycznia 2010 roku ${ }^{17}$. Sąd Najwyższy stwierdzał:

Zgodnie ze stanowiskiem Sądu Najwyższego zaprezentowana przez Kazimierę Szczukę parodia głosu spikerki oraz towarzyszące tej wypowiedzi komentarze Kuby Wojewódzkiego naruszały uczucia religijne osób wierzących, były wyrazem traktowania modlitwy w sposób prześmiewczy i pogardliwy.

Sąd Najwyższy podkreślił, przywołując orzecznictwo Europejskiego Trybunału Praw Człowieka, iż wolność wyrażania opinii nie jest wolnością absolutną i może doznawać ograniczeń na zasadach określonych w art. 10 ust. 2 Europejskiej Konwencji o Ochronie Praw Człowieka i Podstawowych Wolności.

Dwa lata później Krajowa Rada znów zajęła się programem Kuba Wojewódzki, wtedy już jednak emitowanym w TVN. Jej uwagę zwróciła audycja, w której prowadzący zorganizował happening: poprosił swoich gości o wtykanie miniaturowych polskich flag w atrapy psich odchodów (zainspirował się rysunkiem satyrycznym Marka Raczkowskiego). Odwołała się do artykułu 18 (w zakresie ustępu 1, 2 i 3) oskarżając stację o znieważenie symbolu narodowego i nakładając karę w wysokości 471 tys. zł. Obie strony weszły na drogę sądową. W sierpniu 2009 roku Stołeczny Sąd Gospodarczy orzekł, że do

14 Krajowa Rada Radiofonii i Telewizji, Sprawozdanie Krajowej Rady Radiofonii i Telewizji z rocznego okresu działalności, Warszawa, marzec 2000, s. 150, http://www.krrit.gov.pl/Data/Files/_public/Portals/0/ sprawozdania/spr2000/spr2000.pdf (09.08.2011).

15 Krajowa Rada Radiofonii i Telewizji, Sprawozdanie Krajowej Rady Radiofonii i Telewizji z rocznego okresu działalności, Warszawa, marzec 2002, s. 134, http://www.krrit.gov.pl/Data/Files/_public/Portals/0/ sprawozdania/spr2002/spr2002.pdf(09.08.2011).

16 Krajowa Rada Radiofonii i Telewizji, Sprawozdanie Krajowej rady Radiofonii i Telewizji z działalności w 2007 roku, Warszawa, marzec 2008, s. 16, http://www.krrit.gov.pl/Data/Files/_public/Portals/0/sprawozdania/spr2008/spr_2008.pdf, (11.05.2012). Zob. także Wyrok Sądu Apelacyjnego w Warszawie z dnia 8 października 2008 roku, sygn. akt VI ACa 332/08.

17 Wyrok Sądu Najwyższego z dnia 14 stycznia 2010 roku, sygn. akt III SK 15/09. 
znieważenia nie doszło: audycja oceniana jako całość nie propaguje znieważania flagi narodowej, miała charakter satyryczny i wyrażała protest przeciw zanieczyszczeniu ulic ${ }^{18}$.

Inny wyrok zapadł jednak w Sądzie Apelacyjnym, do którego odwołał się przewodniczący KRRiT. W sierpniu 2011 roku orzekł, że TVN musi jednak zapłacić karę finansową nałożoną przez Krajową Radę. Uzasadniał, że zgodnie z polskimi unormowaniami otaczanie czcią symboli narodowych, w tym także flagi, jest prawem i obowiązkiem każdego obywatela. Analizowana audycja tymczasem wyrażała zupełny brak szacunku dla flagi narodowej. Sąd zauważał również, iż takie zachowanie jest ponadto sprzeczne z moralnością ${ }^{19}$.

Inna decyzja (z dnia 29 kwietnia 2011 roku), w której Krajowa Rada również odwołuje się do artykułu 18 (ustęp 1), a dokładniej do zapisów zakazujących emitowania treści dyskryminujących ze względu na narodowość, dotyczy Radia Maryja. Zdaniem organu regulacyjnego (swoją opinię opiera na ekspertyzie prawnej autorstwa prawników z Uniwersytetu Warszawskiego) nadawca naruszył normy ustawowe, emitując w audycji z 13 marca 2011 roku wypowiedzi Jana Kobylańskiego, prezesa Unii Stowarzyszeń i Organizacji Polonijnych Ameryki Łacińskiej. Prezes najpierw wskazywał, że Polską nie rządzą Polacy i dlatego w kraju dzieje się coraz gorzej, a później nawoływał, aby w czasie wyborów głosować tylko na prawdziwych Polaków (w oparciu o kryterium bycia prawdziwym Polakiem, Polakiem - katolikiem radził też konstruować listy wyborcze). Przewodniczący KRRiT wezwał Radio Maryja do zaniechania działań w postaci emitowania audycji, które mogą zawierać treści dyskryminujące ze względu na narodowośćc ${ }^{20}$.

Czy rzeczywiście powyższe wypowiedzi Jana Kobylańskiego powinny wywołać reakcję organu nadzorującego media? Prawnicy, których opinią posłużyła się KRRiT, wskazują, że wypowiedzi propagowały dyskryminację tych, którzy nie należą do katolickiej wspólnoty wyznaniowej i ocenianie (selekcjonowanie) ludzi według kryteriów etnicznych. Zaznaczają, że analizowane wypowiedzi raczej nie należą do tych, które mogłyby wywołać działanie ze strony sądu czy prokuratury, ale Krajowa Rada może w większym zakresie uznawać, że coś jest niedopuszczalne. Chroni ona wolność słowa, ale i interes publiczny. W tym wypadku interes publiczny powinien przeważyć nad wolnością słowa, dlatego jej reakcja jest jak najbardziej wskazana. W opinii zwrócono uwagę także na fakt, że Radio Maryja jest nadawcą społecznym, a zatem przyjmującym na siebie szersze obowiązki w zakresie emitowanych treści niż inni nadawcy ${ }^{21}$.

\section{OCHRONA NAJMLODSZYCH WIDZÓW PRZED SZKODLIWYMI TREŚCIAMI}

Większą aktywność w pociąganiu nadawców do odpowiedzialności za rodzaj emitowanych treści wykazywała Rada w zakresie przestrzegania ograniczeń dotyczących

18 Są: TVN nie znieważyt polskiej flagi, http://wiadomosci.gazeta.pl/wiadomosci/1,114873,6968212, Sad_TVN_nie_zniewazyl_polskiej_flagi.html (24.04.2011).

${ }_{19}$ Krajowa Rada Radiofonii i Telewizji, Komunikat prasowy z 11.08.2011: TVN musi zapłacić karę, http://www.krrit.gov.pl/Data/Files/_public/pliki/wiadomosci/110811_tvn_kara.pdf (07.08.2012).

20 Decyzja przewodniczącego KRRiT z 11 marca 2011 roku, http://www.krrit.gov.pl/bip/LinkClick. aspx?fileticket=ztwtb3tMAVw\%3d\&tabid=136 (12.05.2011).

21 A. Bodnar, K.Śmieszek, Opinia prawna nt. ewentualnego naruszenia przepisów prawa $w$ audycjach nadanych w Radiu Maryja w marcu 2011 r., Warszawa 29 kwietnia 2011 r., http://www.krrit.gov.pl/Data/ Files/_public/Portals/0/wiadomosci/radio_maryja_opinia_krrit.pdf (10.05.2011). 
audycji mogących zagrażać prawidłowemu rozwojowi najmłodszych odbiorców. Być może jedną z przyczyn dużego zainteresowania tym zagadnieniem (oprócz oczywiście chęci chronienia przed nieodpowiednimi treściami najmłodszych odbiorców przekazów medialnych) jest fakt, iż Krajowa Rada została bezpośrednio zaangażowana w formułowanie prawnych ograniczeń. Zapisy artykułu 18, chociaż zmieniały się w toku nowelizacji ustawy o radiofonii i telewizji, zawsze jednak nakładały na Krajową Radę obowiązek wydania rozporządzenia mającego w szczegółach regulować obowiązki nadawców.

Po raz pierwszy przewodniczący Krajowej Rady nałożył karę z racji narażenia najmłodszych widzów na odbiór nieodpowiednich przekazów w 1997 roku. Ukaranym nadawcą była telewizja Polsat. Za emisję o godz. 20 filmu Ostry poker w małym Tokio miała zapłacić 300 tys. zł. Organ nadzorczy podnosił, że nie może pozostać bezkarna sytuacja, kiedy telewizja pokazuje w czasie największej oglądalności film, w którym w sumie dochodzi do 63 zabójstw i 40 scen pobicia, a łączny czas trwania scen przemocy i strzelaniny wynosi 34 minuty, co stanowi około 50 proc. czasu ekranowego ${ }^{22}$ oraz że stacja nie pofatygowała się nawet, żeby ostrzec widzów przed tym, co film zawiera $^{23}$. Nadawca nie zamierzał godzić się z decyzją i oddał sprawę (zgodnie z tym, co przewiduje ustawa o radiofonii i telewizji) do Sądu Gospodarczego w Warszawie. Doszło do zawarcia ugody między stronami, na mocy której Polsat został zobowiązany do wypłacenia 110 tysięcy złotych na cele charytatywne ${ }^{24}$.

W następnym roku Krajowa Rada miała dwukrotnie zastrzeżenia do działalności programowej telewizji Canal Plus. Potępiła ją za nadanie o godzinie 20 filmu Crash (Rada relacjonowała w swoim sprawozdaniu: „Film zawiera sceny ukazujące poszarpane w wypadkach samochodowych ciała, obrazy, w których powtarzane są katastrofy samochodowe znanych osób [traktowane jako podniety seksualne], tatuowanie blizn powypadkowych, stosunki seksualne z osobami okaleczonymi oraz zdjęcia okaleczeń powypadkowych"25) karząc stację za ten krok kwotą 70 tysięcy złotych. Druga sprawa dotyczyła filmu Zazel. Chociaż został wyemitowany o godzinie 0.45, Rada uznała, że nadawcy należy się za niego kara - przewodniczący ustalił ją w kwocie 30 tysięcy złotych - gdyż prezentuje treści pornograficzne, które przecież na mocy przepisów prawa są w polskich mediach całkowicie zakazane ${ }^{26}$.

W 2001 roku Krajowa Rada po raz pierwszy ukarała nadawcę za wyemitowanie kreskówki. Animowany film amerykański pod tytułem Przygody Freya $w$ kosmosie wyświetlony o godzinie 11 w telewizji TV 4 został uznany przez Radę za nieodpowiedni dla dzieci. Oceniła, że film zawierał sceny drastyczne, nasycone obrazami przemocy o wyjątkowo brutalnym charakterze i wobec tego może mieć negatywny

22 Krajowa Rada Radiofonii i Telewizji, Sprawozdanie Krajowej Rady Radiofonii i Telewizji, Warszawa, marzec 2002, s. 18, http://www.krrit.gov.pl/Data/Files/_public/Portals/0/sprawozdania/spr2002/spr2002.pdf (09.08.2011).

23 T. Mielczarek, Między monopolem a pluralizmem. Zarys dziejów środków komunikowania masowego w Polsce w latach 1989-1997, Kielce 1998, s. 73.

24 Krajowa Rada Radiofonii i Telewizji, Sprawozdanie Krajowej Rady Radiofonii i Telewizji, Warszawa, marzec 2000, s. 22, http://www.krrit.gov.pl/Data/Files/_public/Portals/0/sprawozdania/spr2000/spr2000.pdf (09.08.2011).

25 Krajowa Rada Radiofonii i Telewizji, Sprawozdanie Krajowej Rady Radiofonii i Telewizji, Warszawa, marzec 1999, s. 131, http://www.krrit.gov.pl/Data/Files/_public/Portals/0/sprawozdania/spr1999/spr1999.pdf (09.08.2011).

26 Tamże, s. 132. 
wpływ na psychiczny i uczuciowy rozwój niepełnoletnich widzów. Z tego też powodu przewodniczący Rady zdecydował o obciążeniu nadawcy karą w wysokości 10 tysięcy złotych ${ }^{27}$.

Krajowa Rada dbając o przestrzeganie zakazu emisji audycji źle wpływających na rozwój dzieci i młodzieży, postanowiła bliżej przyjrzeć się programowi Big Brother, który w 2001 roku pojawił się na ekranie telewizji TVN. W swoim stanowisku uznała, że tego rodzaju audycje „mogą być społecznie szkodliwe, a ponadto audycje te są de facto apoteozą knajactwa, głupoty, prostactwa i prymitywizmu. Ukazują i lansują postawy oraz zachowania mogące mieć zdecydowanie niekorzystny wpływ na kształtowanie poglądów, postaw i wzorców zachowań części widzów"28 . Po wydaniu opinii nie wystąpiła jeszcze z decyzją o karze pieniężnej. Dopiero w następnym roku po przeprowadzeniu kilkudniowego monitoringu audycji Big Brother - Bitwa nadawanych w godzinach 11.30 - 13.15 i 20.00 - 20.45 uznała, że nadawca łamie przepisy i nakazała mu zapłacić 300 tysięcy złotych kary. Uzasadniała: „W rozpowszechnionych audycjach prezentowane były sprzeczne z moralnością normy grupowe, a treści erotyczne prezentowane były w oderwaniu od odpowiedzialności moralnej za zachowania związane z erotyczną sferą życia człowieka. Audycje lansowały swobodę obyczajową i zachowania oderwane od uczuć"29. Ostatecznie doszło do zawarcia ugody, a kara została zmniejszona do 150 tys. zł (z tego 100 tys. zł TVN wpłacił na cele społeczne).

Inne przypadki nakładania kar finansowych na nadawców związane są z audycją Nieustraszeni emitowaną w telewizji Polsat. W 2004 roku stacja za nadanie kilku odcinków tej audycji w czasie chronionym otrzymała 400 tys. zł kary, w 2006 roku za tę samą audycję nadaną o godz. 21.30 przewodniczący KRRiT obciążył Polsat półmilionową karą. Nadawca w obu przypadkach odwołał się do sądu. Sąd jednak przychylił się do decyzji szefa Krajowej Rady, wskazując, iż nie ma żadnych wątpliwości, że treści obecne w analizowanych audycjach mogły zagrażać prawidłowemu rozwojowi małoletnich, a zatem powinny zostać wyemitowane po godz. $23^{30}$.

Działania Krajowej Rady skłaniające nadawców do przestrzegania przepisów o ochronie nieletnich i nakładanie sankcji za ich łamanie wśród stacji telewizyjnych wzbudzały kontrowersje. Zwykle po wyznaczeniu im kary stacje nie przyjmowały jej, ale najpierw odwoływały się od decyzji do Sądu Gospodarczego, podnosząc, że w polskim prawie nie ma jednoznacznych kryteriów określających, który film nadaje się do emisji w porze największej oglądalności, a którego w ogóle nie można nadawać w telewizji.

W sprawie emisji o godzinie 20 filmu Ostry poker w matym Tokio w telewizji Polsat w 1997 roku, za który Rada nałożyła 300 tysięcy złotych kary, jej przedstawiciel głosił w sądzie:

27 Krajowa Rada Radiofonii i Telewizji, Sprawozdanie Krajowej Rady Radiofonii i Telewizji, Warszawa, marzec 2002, s. 13, http://www.krrit.gov.pl/Data/Files/_public/Portals/0/sprawozdania/spr2002/spr2002.pdf (09.08.2011).

28 Tamże, s. 14.

29 Tamże, s. 14.

30 Krajowa Rada Radiofonii i Telewizji, Sprawozdanie Krajowej Rady Radiofonii i Telewizji z działalności w 2007 roku, Warszawa, marzec 2008, s. 16, http://www.krrit.gov.pl/Data/Files/_public/Portals/0/ sprawozdania/spr2008/spr_2008.pdf(14.08.2011). 
Przepisy artykułu 18 ustęp 3 ustawy o radiofonii i telewizji ${ }^{31}$ mają jednak charakter norm odwołujących się do ocen etycznych, które są zmienne w zależności od miejsca, czasu, przestrzeni i grupy społecznej. Powołane przepisy są lakoniczne, nie definiują, na czym polega zagrożenie dla dzieci i młodzieży, nie dając tym samym nadawcy żadnych wskazówek. Brak bowiem jakichkolwiek wytycznych, decyzji, kryteriów precyzujących, jak rozumieć i stosować przepisy posiadające nieostrą granicę pojęciową ${ }^{32}$.

Przedstawiciel nadawcy podnosił, że Rada powinna opracować kryteria kwalifikowania audycji pozwalające stwierdzić, czy można je pokazać w czasie chronionym, czy tylko między godziną 23 a 6.

Chociaż nadawca trochę cynicznie bronił się, twierdząc, iż nie wiedział, czy film Ostry poker w małym Tokio może wyświetlić w porze największej oglądalności, w jego argumentacji było sporo racji. Rada powinna była wziąć na siebie ciężar opracowania standardów dla filmów, które mogą być emitowane w określonych porach. Swoją bierność w tym zakresie Rada początkowo tłumaczyła potrzebą wykazywania dużej ostrożności w narzucaniu nadawcom z góry ustalonych wzorców postępowania stawiając na samodzielne wypracowanie norm przez nadawców.

Ten cel - zainicjowanie przez nadawców opracowania wspólnego regulaminu prezentowania na swoich antenach treści, które mogą zagrażać dzieciom i młodzieży - udało się Radzie osiągnać w 1999 roku. Wtedy to bowiem stacje telewizyjne zawarły Porozumienie Polskich Nadawców Telewizyjnych Przyjazne Media ${ }^{33}$. W piśmie zadeklarowały, że „,nadawca przystępujący do porozumienia zobowiązany jest uczynić wszystko, co możliwe, by dzieci i młodzież nie były narażone na oglądanie programów, które nie są dla nich odpowiednie"34. Ideą porozumienia było samoograniczenie się mediów w prezentowaniu przekazów szkodliwych dla nieletnich ${ }^{35}$.

$\mathrm{Na}$ mocy tego porozumienia został opracowany system oznakowań, którego poszczególne znaki ukazujące się na ekranach telewizorów miały informować, czy wyświetlana właśnie audycja jest odpowiednia dla dzieci, czy zabroniona ${ }^{36}$.

Można się jednak pokusić o stwierdzenie, że zarówno zapewnienia o prowadzeniu ostrożniejszej polityki programowej dbającej o interes najmłodszych zapisane w porozumieniu Przyjazne Media, jak i przemyślane stosowanie systemu oznakowań nie zostało przez nadawców zrealizowane. Mówiła o tym Rada już w 2000 roku. Zaraz po zaistnieniu na ekranach telewizorów systemu oznakowań dla trzech kategorii audycji KRRiT podjęła decyzję o przeprowadzeniu monitoringu w tym zakresie. W lipcu i wrześniu

31 Przed nowelizacją ustawy o radiofonii i telewizji z 31 marca 2000 roku zapis o obowiązku ochrony nieletnich przed szkodliwymi treściami znajdował się właśnie w art. 18 ust. 2.

32 M. Piotrowski, Popłatne zabijanie. Polsat w sądzie, „Aktualności Telewizyjne” 1998, nr 3, s. 20.

33 Pod porozumieniem podpisały się: Telewizja Polska, Telewizja Polsat, TVN, Polskie Media (nadawca Naszej TV), Telewizja Niepokalanów, Polska Korporacja Telewizyjna (nadawca Canal Plus), Polska Telewizja Kablowa i Wizja TV.

34 Porozumienie Polskich Nadawców Telewizyjnych „Przyjazne Media”, Materiały, „Zeszyty Prasoznawcze" 1999, nr 1-2.

35 Krajowa Rada Radiofonii i Telewizji, Sprawozdanie Krajowej Rady Radiofonii i Telewizji z rocznego okresu działalności, Warszawa, marzec 2001, s. 75, http://www.krrit.gov.pl/Data/Files/_public/Portals/0/sprawozdania/spr2001/spr2001.pdf (10.08.2011).

36 Trzy rodzaje oznakowań odpowiadały trzem kategoriom audycji: „dla wszystkich”, ,za zgodą rodziców”, ,tylko dla dorosłych”. 
2000 roku sprawdziła jak wywiązuje się ze zobowiązań porozumienia Polsat, TVN, TV4 i Canal Plus. Zauważyła niekonsekwencję w stosowaniu oznaczeń. Nadawcy oznaczając dany film lub audycję określonym symbolem, kierowali się tylko sobie znanymi kryteriami i potrafili te same filmy zaliczać do różnych kategorii. Ponadto stacje telewizyjne często emitowały audycje oznaczone jako ,tylko dla dorosłych” przed godziną 23.00, co zdaniem KRRiT zaprzeczało założeniom porozumienia Przyjazne Media ${ }^{37}$.

Radykalną zmianę w kwestii emisji audycji zagrażających prawidłowemu rozwojowi nieletnich przyniosła nowelizacja ustawy o radiofonii i telewizji z 2 kwietnia 2004 roku. Wprowadzenie nowych zapisów nastąpiło z inicjatywy KRRiT. Ustawa nałożyła na nadawców obowiązek oznaczania audycji symbolami graficznymi. Ich opracowaniem miała zająć się Krajowa Rada. Miała ona także wprowadzić podział małoletnich na kategorie wiekowe i każdej z tej kategorii przyporządkować jej własny symbol graficzny ${ }^{38}$.

Stosowne rozporządzenie Krajowa Rada wydała 23 czerwca 2005 roku $^{39}$. Rozporządzenie to wprowadziło podział małoletnich widzów na cztery grupy wiekowe oraz określiło, jakiego rodzaju treści (jakiego rodzaju wizje świata, wzorce zachowań) dzieci z danej grupy nie powinny oglądać i słuchać (rozporządzenie dotyczyło też treści prezentowanych w radiu). Akt prawny wydany przez KRRiT przedstawił także wzory symboli graficznych oraz zapowiedzi słownych, które nadawcy mają umieszczać na ekranie w trakcie emisji danej audycji lub wygłaszać (w przypadku radia), a które są informacją dla rodziców, dla jakich grup wiekowych dana audycja jest odpowiednia.

W rozporządzeniu Krajowa Rada podała także opis ułatwiający zakwalifikowanie audycji jako tych, które mogą mieć negatywny wpływ na prawidłowy fizyczny, psychiczny lub moralny rozwój małoletnich. Tego rodzaju audycje mogą być emitowane wyłącznie w godzinach od 23 do 6. Dla nich Krajowa Rada również przedstawiła odpowiedni wzór symbolu graficznego i zapowiedzi słownej.

Dbając o ochronę dzieci, Krajowa Rada skupiła się teraz na sprawdzaniu, czy nadawcy stosują wytyczne zawarte w rozporządzeniu. Polegało to zwykle na przeprowadzaniu tygodniowego całodobowego monitoringu programowego lub też miesięcznego monitoringu wybranych rodzajów audycji określonych nadawców i szczegółowym śledzeniu, jakie audycje zostały nadane (jakie zawierały treści) i do jakiej kategorii wiekowej zostały zakwalifikowane. Szczególnie sumiennie Krajowa Rada zrealizowała to zadanie w 2006 roku (był to efekt m.in. zobowiązania Rady przez Sejm do większej ochrony najmłodszych widzów). Po analizie wyników monitoringu doszła do wniosku, że najmłodszym widzom w największym stopniu zagrażają nie sensacyjne filmy fabularne nadawane zwykle o późnych porach, ale emitowane popołudniami seriale fabularno-dokumentalne oraz interwencyjne magazyny reporterów, które opatrzone są przeważnie oznaczeniem „od lat 12”, a tymczasem „obraz świata, jaki ukazują, jest pełen kłamstwa,

37 Krajowa Rada Radiofonii i Telewizji, Sprawozdanie Krajowej Rady Radiofonii i Telewizji z rocznego okresu działalności, Warszawa, marzec 2001, s. 77, http://www.krrit.gov.pl/Data/Files/_public/Portals/0/sprawozdania/spr2001/spr2001.pdf(10.08.2011).

38 Ustawa z dnia 2 kwietnia 2004 roku o zmianie ustawy o radiofonii i telewizji, Dz.U. nr 91, poz. 874.

39 Rozporządzenie Krajowej Rady Radiofonii i Telewizji z dnia 23 czerwca 2005 roku w sprawie kwalifikowania audycji lub innych przekazów mogących mieć negatywny wpływ na prawidłowy fizyczny, psychiczny lub moralny rozwój małoletnich oraz audycji lub innych przekazów przeznaczonych dla danej kategorii wiekowej małoletnich, stosowania wzorów symboli graficznych i formuł zapowiedzi, Dz.U. nr 130, poz. 1089. 
przemocy i występków, a nawet zbrodni. Prezentowany 12-latkom wielokrotnie w ciągu doby, bez dostatecznej przeciwwagi pozytywnej, zagraża zdrowiu psychicznemu i mo-

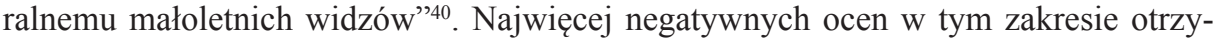
mała telewizja TVN i jej audycje Sędzia Anna Maria Wesołowska, Uwaga, W-11 Wydział Śledczy. (W programach telewizji publicznej KRRiT nie dostrzegła takich audycji, a w Polsacie były one obecne, ale w znikomym stopniu). Dlatego też przewodniczący KRRiT wezwał nadawcę do zaniechania potępianych działań, czyli nadawania analizowanych audycji z zaniżoną kategorią wiekową.

Efektem monitoringu programowego nadawców było też sprawdzanie, czy poszczególnym audycjom, odcinkom seriali i filmom nadawcy przypisują odpowiednią kategorię wiekową. Krajowa Rada dokonywała dokładnych wyliczeń, wskazując, które punkty programu zostały źle zakwalifikowane, tłumaczyła, ze względu na jakie treści nastąpiła błędna kwalifikacja oraz wskazywała prawidłowe oznaczenie. Tego rodzaju wskazówki były bardzo cenne dla nadawców, ponieważ pozwalały im w przyszłości, jeśli wykazywali tylko taką chęć, łatwiej dostosować się do wymagań medialnego regulatora i prawnych regulacji. Krajowa Rada wyznaczała w ten sposób standardy ochrony dzieci przed nieodpowiednimi treściami.

Przeprowadzając owe monitoringi, które skutkowały najczęściej stwierdzeniem sporej liczby nieprawidłowości, Krajowa Rada nie była już jednak skłonna do dyscyplinowania nadawców karami finansowymi i ograniczyła się do wzywania do zaprzestania potępianych praktyk. Przykładem może być tygodniowy monitoring z 2009 roku filmów fabularnych nadawanych w telewizjach satelitarnych TVN7, Ale kino, Canal Plus Polska. W przypadku kanału Ale kino KRRiT stwierdziła błędną kwalifikację aż 4 filmów, z których dwa powinny być opatrzone znakiem „od lat 18” i pokazane po godz. 23 (a były opatrzone znakiem ,od lat 16”). Ale nadawca otrzymał tylko pisemne upomnienie ${ }^{41}$. Nie poniosła też żadnych konsekwencji finansowych telewizja TV4, która dwukrotnie (w 2006 i 2008 roku) upominana była za nadawanie serialu animowanego Włatcy móch o godz. 20. Zdaniem Rady jest to serial dla dorosłych, a zatem musi być emitowany poza czasem chronionym ${ }^{42}$. Z wezwań przewodniczącego KRRiT nie robi sobie nic także telewizja TVN, która nadal nadaje audycję Sędzia Anna Maria Wesołowska w godzinach popołudniowych zamiast po godz. 20. W programach telewizyjnych sporo jest jeszcze innych audycji, które narażają najmłodszych widzów na kontakt z nieodpowiednimi dla nich treściami.

Czy Krajowa Rada zatem dobrze wykonuje swoje zadanie, polegające na pociąganiu nadawców do odpowiedzialności za emitowane treści? Zadanie jest trudne, gdyż w swoich działaniach organ regulacyjny musi z jednej strony brać pod uwagę niezależność nadawców w tworzeniu programu, z drugiej strony dobro odbiorców. Wydaje się,

40 Krajowa Rada Radiofonii i Telewizji, Sprawozdanie Krajowej Rady Radiofonii i Telewizji z działalności w 2006 roku, Warszawa, marzec 2007, s. 48, http://www.krrit.gov.pl/Data/Files/_public/Portals/0/ sprawozdania/spr2007/krrit_spraw_2007.pdf(11.05.2011).

41 Raport z monitoringu wybranych satelitarnych programów filmowych, materiał Krajowej Rady Radiofonii i Telewizji, Warszawa 2010, http://www.krrit.gov.pl/bip/LinkClick.aspx?fileticket=eBETLt7eQzE$\% 3 \mathrm{~d} \&$ tabid= $268(12.05 .2011)$.

42 Informacja o realizacji koncesji w zakresie programu oraz przepisów dotyczących ochrony małoletnich w programach TV4, analiza Biura Krajowej Rady Radiofonii i Telewizji, http://www.krrit.gov.pl/bip/ Portals/0/kontrola/program/tv4maloletni_koncesja.pdf (12.05.2011). 
że Krajowa Rada w ostatnich latach przyjęła taktykę monitorowania nadawców, wskazywania błędów, pouczania, pokazywania prawidłowej drogi postępowania, ale bez nakładania dotkliwych kar. Z jednym wszak wyjątkiem. Przewodniczący KRRiT karze, gdy jakaś audycja wzbudzi kontrowersje społeczne i do Rady napłynie duża liczba skarg. Tak jak w przypadku odcinka Rozmów w toku z października 2010 roku Najlepsza na świecie jest miłość w klozecie (do Krajowej Rady wpłynęło ponad 800 skarg). TVN otrzymał 300 tys. zł kary, gdyż - jak uzasadniał przewodniczący Krajowej Rady - ,prezentowane w audycji relacje młodych kobiet o prowadzonym przez nie życiu seksualnym stanowiły obraz współżycia seksualnego sprzeczny z moralnością i dobrem społecznym”43, a audycja została nieprawidłowo opatrzona znakiem „od lat 12” i pokazana o godz. $15.55^{44}$.

\footnotetext{
43 Decyzja przewodniczącego KRRiT z 11 marca 2011 roku, http://www.krrit.gov.pl/bip/LinkClick. aspx?fileticket=ztwtb3tMAVw\%3d\&tabid=136 (12.05.2011).

44 Tamże.
} 